УДК 811.131.1: 81'255.2

DOI https://doi.org/10.32447/2663-340X-2020-8.3

\title{
ЛІНГВОКУЛЬТУРНА АДАПТАЦІЯ ВУЛЬГАРИЗМІВ В УКРАЇНСЬКОМОВНИХ ПЕРЕКЛАДАХ СУЧАСНОЇ ІТАЛІЙСЬКОЇ ПРОЗИ
}

\author{
Бумар Крістіна Сергївна \\ аспірантка, \\ викладач кафедри романської і новогрецької філологї та перекладу \\ Київського начіонального лінгвістичного університету \\ вул. Велика Васильківська, 73, Київ, Україна
}

\begin{abstract}
Метою статті є виявлення шляхів відтворення вульгаризмів та потенціалу застосування лінгвокультурної адаптації в українськомовних перекладах сучасної італійської художньої прози. Для досягнення иієї мети ми застосували методологічний інструментарій перекладацького аналізу у лінгвокультурному аспекті, який визначає лексико-семантичні особливості ненормативної лексики при перекладі. Жаргон, розмовна мова, вульгаризми є прийомами вираження думок, емоцій, ставлення до соціального навколишнього середовища оповідача у лінгвокультурному аспекті. Таким чином лінгвокультурна адаптація вульгаризмів - це культурно мовленнєва пристосованість до особливості мови різних сочіальних класів. Вульгаризми - изе дзеркало комунікативної поведінки людини, а також національної культури. Ця лексика нині використовується не лише в усному мовленні, а й виходить за його рамки, зокрема, є часто вживаною авторами у сучасному художньому італійському тексті з метою формування образів персонажів та чіткішого окреслення їхніх соиіальних відносин та ставлення героїв до тої чи іншої ситуації у творі. Переклад нерідко залежить не тільки від культури першотвору, а й також від особистості та фонових знань перекладача. Італійська та украӥнська мови мають фонетичні, лексичні, граматичні та стилістичні відмінності, тому переклад вимагає від медіанта пошуку відповідності з метою досягнення перекладацької еквівалентності та здійснення трансформацій, щчо представляють собою складний семантико-когнітивний та лінгвопрагматичний прочеси. Перекладацький аналіз українськомовних перекладів творів Андреа Каммілері «Почерк мития» (пер. А. Маслюх), Донато Каррізі «Ловець невинних душ» (пер. О. Ховрасьова), Паоло Джордано «Самотність простих чисел» (пер. А. Маслюх) довів, щзо перекладачі, для відтворення лексичних одиниць, вдаються до різних стилістично забарвлених слів, фразеологічних одиниць, ідіом, синонімів тощзо. Лінгвокультурна адаптачія вульгаризмів має свої особливості: задля підкреслення ставлення персонажа до іншого героя чи ситуаиії, перекладач має завдання передати це у творі. У статті доведено, що в украӥнськомовних перекладах італійської прози, вирімуючи проблему передачі вульгаризмів, перекладач йде трьома можливими шляхами: пом'якшення, цензурування, або абсолютне збереження.
\end{abstract}

Ключові слова: вульгаризми, розмовна мова, культура, переклад, соціально маркована лексика, лінгвокультурна адаптація.

Постановка проблеми в загальному та обгрунтування ії актуальності. Питання взаємозв'язку мови та культури є одним із найактуальніших питань у лінгвістиці. Мова відображає культурний досвід людей, світогляд, менталітет, систему цінностей, віру та традиції.

Одне 3 найбільш проблематичних питань в теорії перекладу та соціолінгвістиці є питання перекладу вульгаризмів та інших видів соціально маркованої лексики у художньому тексті. Через значну кількість перекладної художньої літератури, це питання останні декілька десятиліть турбує перекладознавців. Тому що така специфічна лексика має бути відповідно перекладена і детермінована сюжетним ланцюжком у художньому прозовому творі. Дослідження перекладу просторічної лексики, функціонування та класифікація понять має великі перспективи і продовжує бути актуальним у сучас- ній лінгвістиці. Актуальність статті полягає у іiі спрямованості на одне з питань, до якого прикута увага сучасних перекладознавців і перекладачів художнього тексту, а саме на дослідження шляхів відтворення соціально маркованої лексики, вульгаризмів зокрема, 3 огляду на авторську інтенцію художнього тексту щодо наближення до усного мовлення через сучасну літературну, культурну та історичну традицію.

Формулювання мети i завдання статті. Метою статті $є$ виявлення потенціалу лінгвокультурної адаптації при перекладі вульгаризмів у сучасній італійській художній прозі українською мовою, зокрема вживання такої розмовнопросторічної лексики у тексті перекладу, яка $є$ тотожною або аналогічною лексичним одиницям тексту оригіналу. Досягнення мети дослідження передбачає вирішення таких завдань: уточнити поняття вульгаризм; виявити його 
лінгвокультурну значимість в семантичному просторі італійської мови; окреслити шляхи відтворення вульгаризмів в українськомовних перекладах сучасної італійської художньої прози.

Аналіз останніх досліджень і публікацій. Питанням вирішення проблем перекладу розмовної мови та вульгаризмів займалися такі відомі вчені: С. І. Влахов, С. П. Флорін, Ю. А. Найда, Л. Венуті, Г. Турі, Дж. Холмс, У. Эко, Л.Л. Нелюбін, С. Б. Велединська, Л. О. Ставицька, О. Горбач та ін.

Однак, особливості відтворення вульгаризмів при перекладі на українську мову в лінгвістиці присвячено не так багато робіт, можемо назвати лише декількох науковців: Є. I. Скворцова, О. I. Чередниченко. Також стаття Ю. М. Плетенецької «Переклад жаргонізмів, сленгу, вульгаризмів та різновидів соціального діалекту в творі Дж. Селінджера «Над прірвою в житі» (2016) висвітлює деякі питання на проблему перекладу соціально маркованої лексики.

Виклад основного матеріалу дослідження.. В період глобалізації на сучасному етапі перекладознавство в цілому переживає своєрідну «культурну революцію». Переклад розглядається як явище не стільки лінгвістичне, як культурне. В теорії перекладу нове осмислення сутності і природи перекладу отримало назву «культурного повороту». Власне кажучи цей термін означає зміщення акцентів у вивченні перекладу на його культурні аспекти і відповідає назві нового «культурологічного» напряму, який, як передбачила М. Снелл-Хорнбі $[10,27]$ стало особливим для перекладознавчої науки. Культурна наукова парадигма передбачає розуміння національної літератури як своєрідної «літературної системи», яка створюється і існує в певному середовищі, що формується соціальною і культурною системою. Всі системи відкриті і взаємодіють один 3 одним. В нашій розвідці культура - це фундамент, на якому будується дослідження проблем перекладу вульгаризмів.

Згідно з думкою Т.С. Некряч [4, 14-15], культурна основа для перекладу набуває різних форм: від лексики та синтаксису до ідеології i способу життя в певній культурі. Переклад художнього тексту - це відтворення максимально наближеної вихідної картини світу, яка виражає етнокультурну специфіку соціуму. Перекладач має дослідити особливості, що відрізняють картину світу автора оригінального тексту від його власної, і визначити, які саме особливості виражені у тексті твору. Відтак задача перекладача - це знаходження оптимальних засобів для відтворення цих особливостей при перекладі.
Для того, щоб адекватно перекласти текст, в якому присутні реалії, фразеологізми, соціолекти, відображені національні особливості культури, перекладач повинен добре знати культуру того, чи іншого народу, на мові якої написаний твір. Адаптація таких текстів $є$ соціокультурною і лінгвістичною, тому може називатися лінгвокультурною.

Тому наголосимо, що лінгвокультурна адаптація - це пристосування явищ іншомовного тексту до соціально-культурної дійсності носіїв перекладного тексту. I за думкою М.О. Федоров $[6,84]$ лінгвістична адаптація це своєрідне «вписування» тексту перекладу в матрицю приймаючої лінгвокультури, тобто адаптація явищ тексту під взаємодією лінгвокультури тексту оригіналу і перекладного тексту. Даний фактор часто застосовується не тільки до окремих явищ тексту оригіналу, а до всього тексту в цілому. Тому, враховуючи даний чинник перекладного явища і реалій, які не повинні «вибиватися» із світогляду носіїв приймаючої культури, вони повинні бути знайомі і звичні читачам.

Як зазначають Н. Ю. Нелюбова і П. С. Фоміна $[5,212]$ негативна сторона даного виду адаптації полягає в тому, що в результаті ії застосування може бути втрачена значна частина культурно специфічних елементів оригінального твору. Нелітературна лексика, пише А. Р. Зубрик $[2,68]$, вважається складною 3 погляду перекладу, оскільки часто деякі вульгаризми можуть бути незафіксованими у словниках через їх зникнення. Тому задля збереження та адекватної передачі вульгаризмів на українську мову перекладачі вдаються до різних перекладацьких трансформацій та стратегій. Найчастіше перекладачі використовують лексико-семантичні та лексико-граматичні трансформації. Також звертається увага на структуру тексту, його обсяг може розширитися / зменшитися, а отже, в тексті передбачаються редукція / ампліфікація / елімінація. 3 семантико-лексичної точки зору специфічним для перекладу вульгаризмів $€$ використання лексико-семантичних перетворень різного рівня складності.

Щоб зрозуміти термін «вульгаризми» необхідно зазначити, що ж являє собою в першу чергу «розмовна мова», з якої і випливає вищезгадане поняття.

Розмовна мова в італійському художньому прозовому тексті характеризується вживанням розмовної лексики і фразеології, переважно короткими, простими синтаксичними конструкціями. В італійському художньому тексті у вигляді розмовної мови поширені також 
звороти, синтаксичні конструкції, що передають безпосередню реакцію персонажа - прохання, здивування, схвалення, заперечення, відмову щось зробити, незадоволення, радість тощо.

Вульгаризми ж є одним з компонентів розмовної мови. Тобто розмовні слова з негативним відтінком.

Як тлумачить словник Treccani, вульгаризмами називаються грубі слова або вирази, народні слова, які знаходяться за межами літературної лексики. Allocco, donnaccia, fannullone, pigrone, scoreggia, uggioso - ці прості, навіть, грубі, неприйнятні в поетичному мовленні лексеми зустрічаються в італійській художній літературі переважно у мові персонажів як засоби мовної характеристики. Основними конструктивними елементами створення розмовно-побутового стилю, використовуються як засіб стилізації розмовної, невимушеної мови, в прямому або внутрішньому мовленні персонажа. Вульгаризми практично не зустрічаються в авторському монологічному тексті.

Будь-яке дослідження вульгаризмів та просторіччя перетинається 3 літературною мовою $\mathrm{i}$ буде, на нашу думку, найповніше реалізовано через дослідження перекладів художньої прози. Оскільки пошук еквівалентів і адекватна передача ненормативної лексики, просторічних слів, розмовних виразів $є$ одним з найскладніших завдань перекладача через культурний та концептуальний зміст. Тому для вирішення цієї проблеми фахівці використовують різні стратегії.

Ненормативна лексика в італійській мові взаємодіє з загальноприйнятими стилістично-експресивними словами, потрапляючи передусім до художніх текстів. А художня проза займає особливе місце в царині письмового слова, місце, яке, на нашу думку, не далеко від розмовної мови. Тому що дійсними хранителями культури $\epsilon$ тексти. Саме текст пов'язаний з культурою, бо він пронизаний культурними кодами, саме текст зберігає інформацію про історію, етнографію, національну психологію, національну поведінку тощо, про все, з чого складається культура [3]. Художнє слово відображає життя суспільства та всі його прояви, а вульгаризми сприяють цьому і так чи інакше надають персонажам особливої характеристики.

Переклад вульгаризмів в італійській художній прозі має свої особливості, адже цей вид соціолекту в італійській мові виступає як культурне надбання. Численні приклади італійських вульгаризмів та просторічних виразів беруть свій початок від історичних жаргонізмів злочинного світу, від мафіозних угруповань Каморра, Ндрангета, від рекетирів ще у XIX ст. $[8,354]$.
Ф. Скальйоне [7, 191] пише, що «розмовну італійську насправді слід розуміти як макрорізноманіття, що характеризується гетерономічним статутом, в якому великий обмін явищами, характерними для неостандарту, супроводжується помітною наявністю регіональних, підстандартних/народних рис та використанням діалекту.

Як показує зібраний нами матеріал, італійські письменники загалом вживають вульгаризми, щоб показати емоційний стан героя, його характер та ставлення до певної ситуації. Зважаючи на те, що даний соціолект має статус культурного надбання, стає очевидною відповідь на питання, чому письменники тяжіють до вживання цього вульгаризмів. Можливо тому, що ця лексика містить в собі той колорит, який притаманний переважно злочинному та низько соціальному середовищу, або мовленню молоді.

Наведемо приклади вульгаризмів 3 італійських художній творів та їхні україномовні переклади:

\section{Merda. - А, що за чортівня!}

Лексема merda в переносному значенні вживається у виразах типових для вульгарного, просторічного мовлення та означає «лайно», «чортівня» тощо. Цей вульгаризм використовується письменниками в декількох значеннях: 1) при описі людини чи речі в зневажливому ставленні, наприклад: lo considero proprio una merda; questo vestito, dopo lavato, è diventato una merda; faccia di merda, pezzo di merda, sacco di merda тощо. 2) Комплекс критичних обставин, безвихідних ситуацій, або таких ситуацій, що створюють значні роздратування та незручності: essere, finire, trovarsi nella merda, nella merda fino al collo; levare, togliere uno dalla merda; È per questo che New York ha tutta questa energia. Perché tutti sanno di poter finire nella merda da un momento all'altro (Rossana Campo). 3) Як вираз обурення, гніву, або відвертої відмови: merda! У нашому випадку, в оригіналі ми бачимо вульгаризм, який передає обурення та гнів. Український переклад виконаний доречно та переданий синонімічним еквівалентом.

2. Cazzo, Salvo, sei un dio! - Сальво, чортяко, ти - геній!

Слово cazzo в італійські лінгвокультурі є доволі грубим виразом, має низький розмовний реєстр, може належати як до ненормативної лексики, так і до розмовної мови. Перекладач зберіг семантику слова, але задля цензурного перекладу використовує синонім соціально маркованої лексеми оригіналу. Слово часто висловлює власну думку до чогось, зацікавленості у виразах типу: un libro del cazzo; un film, un discorso, uno spettacolo del cazzo. У цих та 
багатьох інших локусах, а також як вигук, здивування, нетерплячість, гнів, розчарування тощо. В оригінальному прикладі автор явно вживає дану лексему у грубій формі, що змушує перекладача вдатися до цензурованого варіанту та лексичної трансформації.

3. Саzzo, ma non è possibile! - Трясия його мaтері, це неможливо! - Знову зустрічаємо вульгаризм cazzo, який в перекладі переданий лайливим фразеологічним виразом. Перекладачка О. Ховрасьова теж пом'якшує переклад, використовуючи лексичну трансформацію. Переклад невдалий, на нашу думку, перекладачці не вдалося передати прагматичне значення слова, $\mathrm{i}$ було б доречно використати інший вульгаризм, який більш відповідає характеру персонажа поліцейського в ситуації, що склалася в тексті. Поліцейські, які шукають докази, знаходять зовсім інше, і це заводить одного 3 правоохоронців у глухий кут. Тому краще було б перекласти «Чорт, це не можливо!».

Для італійської лінгвокультури лайливі фрази одні з найважливіших елементів тексту. Тому, передаючи їх при перекладі, варто пам'ятати, чи доречна фраза буде для української лінгвокультури.

4. E allura che minchia dicevo? - То про шо ми тут, до холсри, говорили?

Вульгаризм minchia дослівно означає «чоловічий статевий орган», а конотативне значення слова часто зустрічається як вигук (здивування тощо), або як образливі вирази: ніфіга собі!, чорт забирай! Лексема перекладена доречно. При перекладі використано синонімічний еквівалент та стилістичну трансформацію.

5. Sei proprio uno stronzo. - Ну й сволота ж ти!

Іменник stronzo у словнику має дуже багато значень. Загалом лексема використовується у лайливому контексті і має значення «гівнюк», «сволота», «мудак» тощо. Вульгаризм перекладений доречно українським синонімічним еквівалентом.

\section{6. Ѐ una stronzata disse. - Що за idiomизм!}

Фраза «Е una stronzata» передає дію, або дурну поведінку нерозумної людини. Сама лексема stronzata означає «маячня», «гидота», «лайно» тощо. Переклад виконаний доречно, перекладач пом'якшує значення слова, використовуючи в українській мові синонімічний еквівалент.

Отже, 3 аналізу вищенаведених прикладів можна констатувати той факт, що вульгаризми $\epsilon$ соціолінгвістичним та лінгвокультурним феноменом. Відтворення італійської ненормативної лексики українською мовою показало, що перекладачі досить добре справилися зі своїм завданням. Перекладач А. Маслюх прагне максимально передати сенс вульгаризмів, однак все ж таки пом'якшує їхнє значення, залишаючи експресивну сторону слів. Тому що пом'якшуючи, або цензуруючи даний соціолект перекладачу важливо пам'ятати про комунікативну експресивну роль слова для виявлення афекту.

Перекладачами вдало були підібрані варіанти перекладів слів stronzo та cazzo. Як наголошує А.А. Білас [1, 68-69], що при перекладі зниженого розмовного дискурсу можливе використання синонімів, що відрізняються значенням, експресивним, емоційним чи стильовим забарвленням. I водночас у процесі перекладу ненормативної лексики відбуваються неминучі втрати, оскільки вони мають яскраво виражене національне забарвлення, і для їх передачі не завжди вдається використовувати відповідні пласти мови перекладу. Тому у разі правильного вибору стратегії перекладу, грунтуючись на детальному аналізі стилістичних прийомів автора твору, перекладач може найточніше передати той ступінь впливу, який зазнається при читанні оригінального тексту.

В результаті нашого аналізу можемо зазначити, що найкращим рішенням при перекладі вульгаризмів $\epsilon$ використання функціональних аналогів та варіативних еквівалентів за наявності їх в мові перекладу. Якщо контекст змушує відмовлятися від вибору однієї з варіантних відповідностей, тоді доводиться шукати новий варіант перекладу - синонімічну заміну. Через вульгаризми найкраще проявляється характер героїв, їхнє соціальне пристосування та приналежність. Тому, найголовніше в перекладі ненормативної лексики проявити і мову автора, і мову персонажів художнього тексту.

Висновки 3 дослідження і перспективи подальших досліджень. В художній прозі зустрічається різноманітна соціально маркована лексика, яка не завжди при перекладі зберігає релевантне значення. Тому відтворення вульгаризмів, як одного з видів соціально маркованої лексики відбувається за допомогою еквівалентів або стилістично забарвленої лексики мови перекладу. Підбиваючи підсумки, зазначимо, що в сучасних італійських художніх текстах автори використовують значну кількість розмовно-просторічних слів та вульгаризмів, завдяки яким утворюється певна лінгвокультурна картина. Тому вульгаризми інколи викликають складну проблему для перекладу. Проведений аналіз довів, що перекладачі знаходять лексичні еквіваленти і адаптують їх до української лінгвокультури, намагаючись зберегти авторський стиль та інтенцію мовлення персонажів. 
Перекладацький аналіз вульгаризмів у сучасній італійській художній прозі має перспективи подальшого дослідження із залученням більшої кількості практичного матеріалу та творів інших сучасних авторів італійської прози, а також вивчення лінгвокульторологічних особливостей перекладу.

\section{ЛIТЕРАТУРА}

1. Білас А. А. Операційний інструмент перекладу французької зниженої розмовної лексики. Науковий вісник Чернівецького університету. 2013. Вип. 645. С. 65-69.

2. Зубрик А.Р. Перекладацький аспект нелітературної лексики у творах художньої літератури. Науковий вісник ДДПУ імені І. Франка. Серія «Філологічні науки». Мовознавство. № 7, 2017. С. 67-70.

3. Лингвокультурный аспект русской фразеологии. Textologia. Ru. [Режим доступу]. Access: http://www.textologia.ru/yazikoznanie/lingvokulturologia/lingvokulturnyj-analiz/lingvokulturniy-aspekt-russkoyfrazeologii-prodolzhenie/1924/?q=641\&n=1924 (дата звернення 17.03. 2020)

4. Некряч Т.С., Чала Ю.П. Через терни до зірок: труднощі перекладу художніх творів. Навчальний посібник. Вінниця, 2008. $200 \mathrm{c}$.

5. Нелюбова Н.Ю., Фомина П.С. Использование приема адаптации при переводе художественных произведений, относящихся к различным типам культур (западной и русской). Весник славянских культур. 2018. Вып. 48. С. 211-225.

6. Федоров М. А. Термин «Лингвокультура» в аспекте теории культуры. Вестник Бурятского государственного университета. 2014. № 6-2. С. 83-86.

7. La lingua variabile nei testi letterari, artistici e funzionali contemporanei: analisi, interpretazione, traduzione : atti del 13. Congresso SILFI : riassunti e testi in cd / raccolti da Francesco Paolo Macaluso. Palermo, 2014. 201 p.

8. Lubello S. Manuale di linguistica italiana. Berlin, 2016. $737 \mathrm{p}$.

9. Perché leggere La chiave a stella di Primo Levi. Laletteraturaenoi [Режим доступу]. Аccess: https://www.laletteraturaenoi.it/index.php/la-scrittura-e-noi/742-perch\%C3\%A9-leggere-la-chiave-a-stella-di-primolevi.html (дата звернення 29.03.2020).

10. Snell-Hornby M. The Turns of Translation Studies. New paradigms or shifting viewpoints? Amsterdam \& Philadelphia: John Benjamins, 2006. 217 p.

\section{REFERENCES}

1. Bilas A. A. (2013). Operacijny'j instrument perekladu franczuz'koyi zny'zhenoyi rozmovnoyi leksy'ky'. [The problems of operational tools in rendering the French low colloquial vocabulary]. Naukovy'j visny'k Chernivecz'kogo universy'tetu. Vy'p. 645. S. 65-69. [in Ukrainian].

2. Zubryk A.R. (2017). Perekladacz'ky'j aspekt neliteraturnoyi leksy'ky'u tvorax xudozhn'oyi literatury'. [Translation aspect of colloquial vocabulary in artistic literature]- Naukovy'j visny'k DDPU imeni I. Franka. Seriya «Filologichni nauky'». Movoznavstvo. №7. S. 67-70. [in Ukrainian].

3. Lingvokyl'typnyj acpekt pycckoj fpazeologii. Textologia. Ru. [Rezhym dostupu]. Access:http://www.textologia.ru/ yazikoznanie/lingvokulturologia/lingvokulturnyj-analiz/lingvokulturniy-aspekt-russkoy-frazeologii prodolzhenie/1924/? $\mathrm{q}=641 \& \mathrm{n}=1924$. [in Russian].

4. Nekryach T.Ye., Chala Yu.P. (2008). Cherez terny' do zirok: trudnoshhi perekladu xudozhnix tvoriv. [Per aspera ad astra: difficulties in translating works of art]. Navchal'ny'j posibny'k. Vinny'cya: Nova Knyga. 200 s. [in Ukrainian].

5. Neljubova N.Ju., Fomina P.S. (2018). Ispol'zovanie priema adaptacii pri perevode hudozhestvennyh proizvedenij, otnosjashhihsja k razlichnym tipam kul'tur (zapadnoj i russkoj). [Adaptation tecnique in transtation of literary text of defferent cultures types]. Vesnik slavjanskih kul'tur. Vyp. 48. S. 211-225. [in Russian].

6. Fedorov M. A. (2014). Termin «Lingvokul'tura» v aspekte teorii kul'tury. Vestnik Burjatskogo gosudarstvennogo universiteta. [The term TERM «Linguaculture» in the aspect of the theory of culture]. Vestnik Burjatskogo gosudarstvennogo universiteta. № 6-2. S. 83-86. [in Russian].

7. La lingua variabile nei testi letterari, artistici e funzionali contemporanei: analisi, interpretazione, traduzione: atti del 13. (2014). Congresso SILFI : riassunti e testi in cd /raccolti da Francesco Paolo Macaluso. Palermo. 201 p. [in Italian].

8. Lubello S. 2016. Manuale di linguistica italiana. Berlin. 737 p. [in Italian].

9. Perché leggere La chiave a stella di Primo Levi. Laletteraturaenoi [Rezhy'm dostupu]. Access: https://www.laletteraturaenoi.it/index.php/la-scrittura-e-noi/742-perch\%C3\%A9-leggere-la-chiave-a-stella-di-primolevi.html. [in Italian].

10. Snell-Hornby M. (2006). The Turns of Translation Studies. New paradigms or shifting viewpoints? Amsterdam \& Philadelphia: John Benjamins. 217 p. [in English] 


\title{
LINGUAL AND CULTURAL VULGARISMS ADAPTATION IN THE MODERN ITALIAN PROSE UKRAINIAN TRANSTATIONS
}

\author{
Bumar Kristina Serhiivna \\ Phd Student, \\ Lecturer at the Department of Romance and Modern Greek Philology and Translation \\ Kyiv National Linguistic University \\ Str. Velyka Vasylkivska, 73, Kyiv, Ukraine
}

The paper aimi to identify ways to reproduce linguistic and cultural adaptation vulgarisms and the potential in modern Italian fiction Ukrainian translations. To achieve this goal, we used the translation analysis methodological tools in the linguistic and cultural aspect, which determine the non-normative vocabulary lexical and semantic features in translation. Jargon, colloquial language, vulgarisms are expressed thoughts methods, emotions, attitude to the narrator social environment in the linguistic and cultural aspect. Thus, the lingual and vulgarisms cultural adaption is a culturalspeech adaptation to the different social classes language peculiarities. Vulgarisms are a human communicative behavior mirror, as well as national culture. This vocabulary is now used not only in oral speech, but also beyond it, in particular, is often used by authors in modern Italian art text to characterise and more clearly delineate form images their social relations and the characters'attitude to a situation in the work. Translation often depends not only on the original culture, but also on the personal and background translators' knowledge. Italian and Ukrainian languages have phonetic, lexical, grammatical and stylistic differences, so translation requires the mediator to find a match in order to achieve translation equivalence and make transformations that are complex semantic-cognitive and pragmatic processes. Ukrainian translation analysis of translations by Andrea Cammileri "Почерк мития" (translated by A. Maslyukh), Donato Carrizi "Ловець невинних душ" (translated by O. Khovrasyova), Paolo Giordano "Самотність простих чисел" (translated by A. Maslyukh) proved that translators, reproduce lexical units, resort to various stylistically colored words, phraseological units, idioms, synonyms, etc. Lingual and vulgarisms cultural adaptation has its own features: in order to emphasize the character's attitude to another character or situation, the translator has the task to convey it in the work. The paper proves that in Ukrainian-language Italian prose translations transmission problem of vulgarities are solved in three possible ways: softening, censoring, or absolute preservation.

Key words: vulgarisms, colloquial speech, culture, translation, social marked vocabulary, lingual and cultural adaptation. 